\title{
Single-father Parenting in Contemporary Russian and Foreign Social Science Research
}

\author{
Popov Viktor Alexeevich ${ }^{1}$, Kanareikina Tatiana Alexandrovna ${ }^{1}$ \\ ${ }^{1}$ The Stoletov Brothers Vladimir State University, Vladimir, Russia \\ Correspondence: Kanareikina Tatiana Alexandrovna. E-mail: canareikina@mail.ru
}

Received: April 24, 2017

doi:10.5539/ass.v14n2p173

\begin{abstract}
The article contains a comparative analysis of Russian and foreign research exploring the phenomenon of single father hood. The most significant pedagogical and psychological aspects of child-rearing in single male parent families dealt with in Russian and foreign studies have been examined along with the results of the authors' empirical research into the characteristics of parental responsibilities and single-father parenting strategies.
\end{abstract}

Keywords: single fatherhood, single-parent families, parenting, education

\section{Introduction}

Both educational establishments at all major stages of education and the family are paramount in enabling a person to form, maintain and develop his or her mental and moral makeup. Family is assumed here to be a major institution through which socialization is achieved in today's world; it was, is and will remain the mainstay of nurturing and shaping a child's personality. The international academic community has largely shared the view that no other upbringing agent can compare to the family in how enduring its impact is (Popov, 2013; Popov \& Anikina, 2014; Camp, 2012; Williams, 2015).

The drastic changes in the institution of fatherhood, brought about by social contradictions, have given rise to special studies of single-father families worldwide. In particular, socio-educational and psychological research in Russia, Britain, USA, Canada and Asia has noted the male roles' marked tendency towards expansion. Our analysis indicates that this social phenomenon has been linked to active propaganda of gender equality, especially in parenting matters, the extension of fathers' parenting functions, and the increase in the number of single-father families. The significant changes in today's public perceptions of the "fatherhood culture" have been due to another set of factors: the destabilization of the motherhood institution and the transformation of women's social roles ranging now from that of the devoted homemaker absorbed entirely in nurturing children to the declaration of women's right for professional self-realization and successful careers. It will be noticed that foreign research on the phenomenon of single fatherhood is comparatively more extensive. This has called for an examination of the international experience with the purpose of its integration into Russian scholarship and practice.

We could not quite agree with the contention of some Russian researchers, that "the role of a father and a male is losing its value" in present-day Russia (Saralieva, Petrova, \& Egorova, 2015, p. 255). On the contrary, it should be emphasized that, according to empirical and statistical data, currently this country has been witnessing a substantial growth of single-fathers' role in parenting as well as an increase in the number of single-parent families in which a male rears children without their mother. The latest official figure is 634,500 single fathers in Russia, which accounts for about $6 \%$ of the total number of sole-parent families (Otsy-odinochki v Rossii, 2010). Besides, the present-day social realities produce lone-fathers not only as a result of divorce, the death of them other or her doing a terminapenal colony, custody removed from the mother due to her inadequate parenting, but also (regardless of any external factors) as a consequence of the father's conscious choice to raise the child by himself, without the mother, which is realized by different means and in various forms, including surrogacy and same-sex marriages. Besides, our analysis of the relevant Russian and foreign cases suggests that every year there are more and more precedents when the father has to uphold his rights in court due to the mother's parental incompetence.

Monitoring the issue has revealed that in the last five years the number of cases in which the Russian courts decide on the child residing with the father has increased by $4 \%$ (Ostavleniye detej pri razvod'e s otsom, 2016). 
S. Garasky (1996) and D. Meyer (1993) maintain that legislation in the West was able to adapt to the new social and cultural realities, and this brought about changes in the laws which enabled fathers to become primary caregivers to their kids. As reported by OECD (OECD, 2011), 15\% of children worldwide belong to single parent families, $85 \%$ and $15 \%$ of which are headed by mothers and fathers, respectively.

According to the 2012 US census, $25.9 \%$ of children under 18 live in single parent families, with $8.4 \%$ supported by divorced fathers, $1.5 \%$ by fathers who have never been married and $0.9 \%$ by widowed fathers. The 2011 Canada census has it that $19.3 \%$ of all Canadian children belong to single parent households, $17.7 \%$ being run by lone fathers (Single parents worldwide: statistics and trends, 2015).

As early as 1980 s, I. S. Kon called attention to the fact that the number of single fathers was increasing, their share in the total amount of families with children ranging from $0.7 \%$ in Spain to $11 \%$ in Italy (frequently these were not divorcees but widowers) (Kon, 1988, p. 272). In Europe it is France which is home to the highest number of single fathers who support $20 \%$ of children aged 13-16. (Otsy-odinichki v Rossii, 2010). In some Muslim countries after the divorce children always remain with the father. In Lebanon, for example, one family out of five is headed by a single male parent (Gomzikova, 2011).

Thus the statistics indicate that the rapid increase of single-father families since the early 1980s is a corollary of the shift in public attitudes to single fatherhood parenting (Otsy-odinochki v Rossiyi, 2010).

Studying external sources we have found that some foreign scholars, including P. B. Barker (1994), D. B. Downey (1994), D. J. Eggebeen (1996), A. P. Snyder (1996), W. D. Manning (1996), S. Garasky (1996), D. P. Meyer (1993), K. McQuillan (1999), M. Belle (1999), L. Williams (2015) on the strength of empirical data noted the burgeoning of single-father families. For instance, in the late 1970s and early 1980s this growth became manifest in US, Canada, Britain and Australia, and it was comparatively greater than that of their single-mother counterparts.

At present the single-father phenomenon has established itself quite firmly all over the world and attracted a lot of interest in social research communities. Russian and foreign scholars have been addressing specific characteristics of single father parenting and their intrinsic dynamics as well as special features of social work with this type of families and the psychology of children raised by single fathers.

Many countries have been launching programs to encourage fathering activities, including single fathers. For example, W. J. Clinton initiated "Save our Children" and "National Fatherhood Initiative" programs. Al Gore, Vice President in Bill Clinton's Administration, sponsored a conference on concerned fatherhood. The US Congress set up the first bi-partisan Congression Task Force on Responsible Fatherhood and passed the appropriate resolution. About 80 per cent of the respondents in the Gallup Institute Poll named fatherhood the most serious social issue of today (Zhouravlev, 2008). Lone Fathers Association Australia which had designed the 'Good to Great' Fatherhood Mentoring Course for the $21^{\text {st }}$ Century, was able to create 'Good to Great' for Single Fathers in late October 2013 which featured unique weekly sessions with Tony Miller (a devoted father of five) and his Dads in Distress (www.dadsindistress.asn.au) and Barry Williams, Lone Fathers Association, with a similar story to tell (www.lonefathers.com.au ).

On the one hand, the findings from a research headed by D. Downey, Department of Sociology, Ohio State University demonstrate that the sex of a parent seems to play no significant role in children' development (J. Grabmeier, 1998), and that the absence of a second parent rather than sex-typed parenting may be the reason for the existing differences in, for example, academic deficits for children (Dufur et al., 2010).

However, we should not overlook the fact that single-fathers' social practices are intrinsically distinctive and that the phenomena of fatherhood and motherhood possess certain inherent dissimilarities. In his book "The Art of Loving" E. Fromm, the great sociologist and psychoanalyst of the twentieth century, pointed out (not without certain qualifications) that motherly love "by its very nature is unconditional. Mother loves the newborn infant because it is her child, not because the child has fulfilled any specific condition, or lived up to any specific expectation. ... Fatherly love is conditional love. Its principle is "I love you because you fulfill my expectations, because you do your duty, because you are like me."(Fromm, 1956).

Our research has shown that single-father parenting involves certain difficulties experienced by fathers in interaction with their children. As we see it, the greatest problem for the single male parentis devising the best strategies and choosing the most appropriate behavior patterns. Parenting strategies will also vary significantly depending on the sex of the child. A single male parent may find mothering duties quite a challenging function, the more so when having to raise a daughter. Setting a female behavior example to his daughter, especially if unaided by a grandmother (the father's mother) or any other close relative, can really be problematic. According 
to the findings from the monitoring program carried out by the Department of Social Pedagogy and Psychology, VISU, the majority of the single fathers (65\%) doubt if they can properly rear their daughters without any female assistance. The single male parents were concerned lest they be unable to cope with fathering duties, particularly when a daughter was involved; they considered themselves sin competent and found it hard to make decisions based on their own intuition without any advice from their wives.

When children first become aware of their sex, they begin to learn crucial behavior patterns: boys assimilate masculinity and girls femininity. It is only natural that no person can perform both family roles - those of mother and father - equally well. Single fathers find it hard to explain to their adolescent daughter what it means to be a woman, whereas with boys a lone dad can inculcate masculinity by personal example. The fact that girls from single-father families are characterized by a higher level of masculinity may be due to their having received sufficient instruction from the father about the value of strength, endurance and independence. Girls who had spent little time with their mother when they were growing up in most cases have "male behaviors", in other words, they fail to acquire the conventional gender stereotype. Our study of adolescent girls from single-father households in the Russian city of Vladimir shows that the majority of the respondents (63\%) favour personal traits typical for males.

However, single-father parenting does have certain advantages. Children in father-only families take less time to become mature and learn to be more responsible for their own well-being. In most cases the child enjoys more attention and care from the single parent.

It should be emphasized that a single parent family is not necessarily an unhappy one. Both social and psychological problems fathers and their children face can be reduced to the minimum through appropriate interaction strategies. The burgeoning single parenting practices furnish enough experience to help neutralize the negative consequences of family break-ups for children. Socio-pedagogical and psychological theories and practices suggest that children from families filled with conflict experience as many problems in their own family relationships as the children raised by a single parent. This has been amply evidenced by the present-day gender-based pedagogical and psychological research. The Russian psychologist I.S. Klyotsina notes that "the gender component of family relations is relatively easy to identify. It manifests itself in the relations between husband and wife, father and daughter, mother and son. The specific gender relationship shave both horizontal and vertical dimensions: the spousal and child-parent relations most clearly exemplify various socio-cultural prescriptions and requirements concerning the content and performance of family roles by men and women. Since family is the sphere in which the two sexes interact directly, it cannot be conceived apart from gender constructs" (Klyotsina, 2011. p. 111). The traditional family model has been gradually replaced by its partnership counterpart. It is not its external parameters that a family's well-being should be measured by, i.e. neither quantitative characteristics (two-parent/single parent family, with children/no children) nor type of family ties (children related by blood/unrelated) etc. The pivotal factor here, recognized by the international scholarship, is the successful character of family relations (Ibid., p.116).

The use of gender perspective in examining the research on family relationships has made it possible to come to the following conclusions: 1) changes within a family are socially and culturally constructed 2) family relationships are dependent on social environments 3 ) types of families and family relationships are not static but dynamic 4) in performing their respective roles within a family men and women are influenced by masculinity and femininity ideologies (Ibid, p. 114).

Russian psychologists today are positive that the corrosive effect of single fathering on the male parent's own destiny is entirely dependent on the caregiver's personality. The lone-fathers, who carry out their duties successfully, point out that fathering contributed to their personal growth and enabled them to discover new facets of life and enjoy enriching experiences (Grozdej, 2011).

\section{Materials and methods}

Our investigation into defining features of lone-fatherhood in Russia was focused on the following major issues:

- Characteristics of single fathers' domain of motivations and needs;

- Lone-fathers' parental responsibility and its levels;

- Analysis of parenting in single fathers' families;

Testing and interviewing were used as research methods. To identify the characteristics of lone-fathers' domain of motivations and needs we employed Y.A. Tokareva's methodology «Fathers' Domain of Motivations and Needs» (FDMN). This standard methodology was published in 2010. The test includes questions distributed into the following scales: social approval motivation, self-realization-in-children motivation, self-development 
motivation, achievement motivation for a better relationship with the child and her/his development, self-assertion motivation. Social approval motivation is characterized by the father's desire to be assessed positively, his need of approval and recognition by others. Self-realization-in-children motivation reflects the father's need for achievement in the domain of self-development through realizing himself as a paternal role model. Achievement motivation for a better relationship with the child and her/his development hinges on the father's need for positive child-parent interaction and his child achieving high results in different activities. Self-assertion motivation indicates the single-father's need to exercise authority, demonstrate how firm his resolution can be (Ovcharova, 2010, p. 77).

To facilitate the study into defining features of lone-fathers' parenting we used the "Conscious Parenting" questionnaire (the male version), worked out by M. S. Ermikhinaunder R.V. Ovcharova's supervision, which was published in 2003. The questionnaire is an effort to translate into practice a systemic diagnosis-and-development approach toward assessing oneself as a parent, one's parental attitudes and expectations, emotions, positions, responsibilities, parenting style, the sources of knowledge and ideas about parenthood. The questionnaire under discussion performs three functions: 1) diagnostic 2) reflexive 3) stimulating. It is used to diagnose how conscious parenting has been. This is achieved through 48 questions, the answers to which are evaluated by using a 5-point scale and analyzed within the framework of the following dimensions: parental positions, parental emotions, parental responsibility, parental attitudes and expectations, parental values, parenting style, parental interaction with the child.

To investigate the lone-fathers' parenting we used S. S. Stepanov's methodology "Parenting strategies" first published in 2000.Thetestcomprisestenquestions, formulated in such a way as to elicit an answer which corresponds to a specific parenting style. The defining features of parenting are analyzed and determined according to which categories of answers are prevalent.

This research was based at Vladimir State University (the city of Vladimir, Russia) and carried out as part of the project "Socio-psychological support for lone-fathers' families".

\section{Results}

99 lone-fathers aged between 34 and 50 took part in the research as respondents, 46 (46,5\%) of them rearing daughters, $53(53,5 \%)$ raising sons.

The study of the single males' parenting activity and its specific components revealed substantial differences in some parameters, depending on the children's gender.

Table 1.

\begin{tabular}{llcc}
\hline № & Single fatherhood motives & Rearing a daughter & Rearing a son \\
\hline 1 & Social approval motivation & $21(45,6 \%)$ & $10(18,9 \%)$ \\
2 & Self-realization motivation & $8(17,4 \%)$ & $24(45,3 \%)$ \\
3 & Achievement motivation (for higher results in child's development) & $12(26,1 \%)$ & $10(19,9 \%)$ \\
4 & Self-assertion motivation & $5(10,9 \%)$ & $9(16,8 \%)$ \\
\hline
\end{tabular}

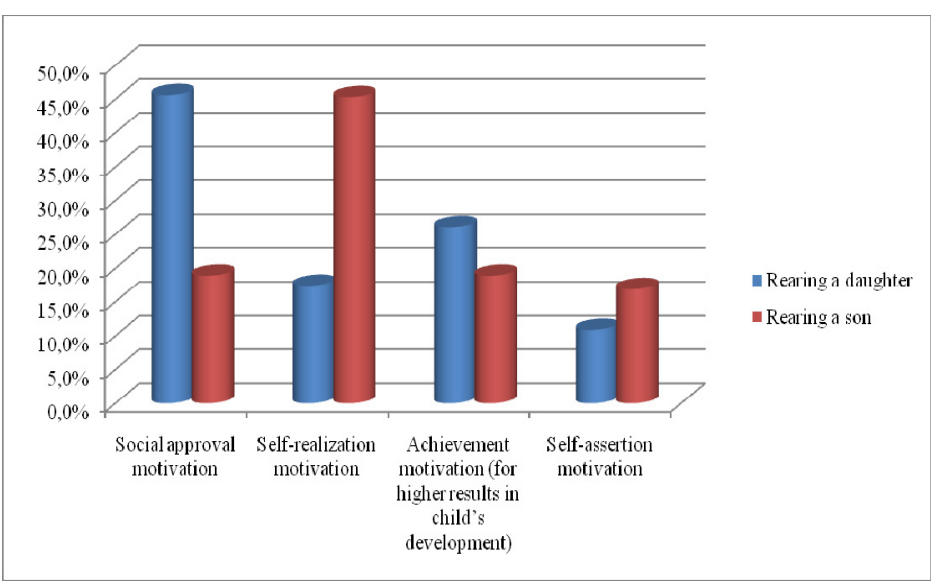

Figure 1.

Social approval motivation is most characteristic of lone-fathers raising daughters $(45,6 \%)$, where as self-realization motivation is typical of those lone-fathers who rear sons $(55,5 \%)$. Social approval and 
achievement motivations $(18,9 \%)$ take second place with single fathers who rear sons without the assistance of the latters' mother. Self-assertion motivation prevails with $16,8 \%$ of the son-rearing respondents. Achievement motivation for higher results in child's development also comes second with the single male parents who raise daughters $(26,1 \%)$, third place being taken by self-assertion $(10,9 \%)$ and self-realization motivations $(17,4 \%)$ (see Figure 1).

The study of parental responsibility levels revealed no substantial differences among the respondents. (Table 2).

Table 2 .

\begin{tabular}{cccc}
\hline № & Levels of Parental Responsibility & Raising a daughter & Rearing a son \\
\hline 1 & High & $23 / 50 \%$ & $25 / 47,2 \%$ \\
2 & Medium & $20 / 43,5 \%$ & $24 / 45,3 \%$ \\
3 & Low & $3 / 6,5 \%$ & $4 / 7,5 \%$ \\
\hline
\end{tabular}

In both groups $(50 \% ; 47.2 \%)$ of those tested have high level of paternal responsibility. In Group1 (lone-fathers raising a daughter) $43.5 \%$ of those tested have medium level of parental responsibility, and those in Group 2 $45.3 \%$; in the said groups low level of paternal responsibility characterizes $6.5 \%$ and $7.5 \%$ of those tested respectively (cf. Figure 2).

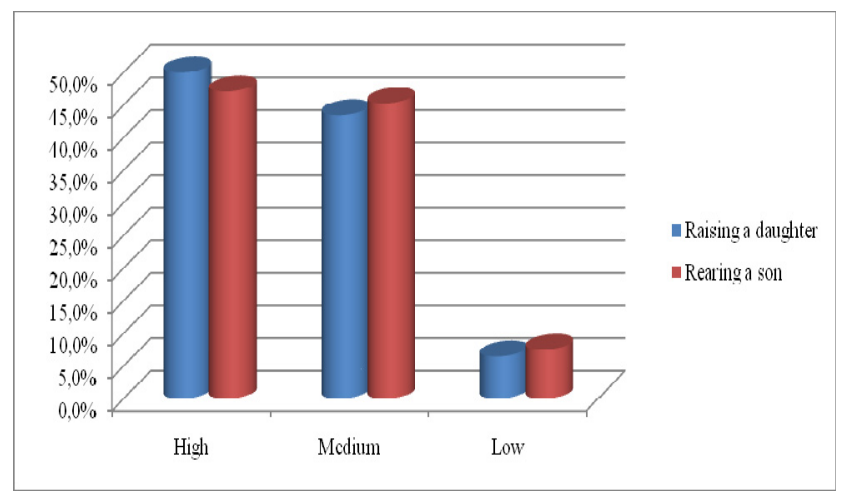

Figure 2.

The results of lone-fathers' parenting style analysis demonstrated that in the families where fathers raise their daughters the prevalent parenting style is the authoritative/democratic one and the authoritarian style prevails in those families where fathers rear their sons (cf. Table 3; Figure 3).

Table 3 .

\begin{tabular}{cccc}
\hline № & Parenting style & Raising a daughter & Rearing a son \\
\hline 1 & Authoritative (democratic) & $23 / 50 \%$ & $17 / 32,1 \%$ \\
2 & Authoritarian & $10 / 21,7 \%$ & $26 / 49 \%$ \\
3 & Liberal & $13 / 28,3 \%$ & $9 / 18,9 \%$ \\
4 & Indifferent & 0 & 0 \\
\hline
\end{tabular}

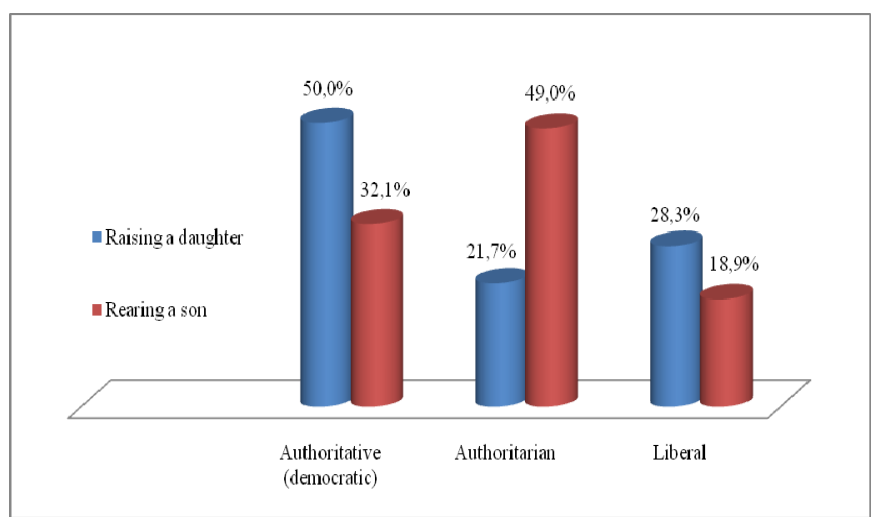

Figure 3.

\section{Discussion}

The analysis of the lone-fathers' parenting characteristics has revealed not only its distinctive gender-related 
features but also similarities in parental responsibility regardless of the child's gender.

\section{Conclusion}

The present analysis of Russian and foreign single-fathering research provides convincing evidence that thus far no well-grounded holistic conceptual approach has been employed to study lone-fatherhood as an integral phenomenon. Not with standing the fact that for Russian society single fatherhood is are latively new and unusual fact of life, we believe that the father can be as successful a parent as the mother. Therefore viewing the father's role as insignificant is, to say the least, unproductive, nor does talking about maternal instincts today get us anywhere. The present-day single father has to play the key role in his family interactions, he certainly does have to shoulder a great burden of material, legal and social responsibilities. Nevertheless, the integration of both inter departmental resources and the international experience in supporting father-only families will make it possible to create optimal social conditions for effective single fathering and successful performance by lone-fathers of their parental duties.

\section{Acknowledgement}

Coordinators’ team and participants in «Socio-psychological support for single-father families» project.

\section{References}

Barker, R. W. (1994). Lone Fathers and Masculinities (p. 281). Brookfield, England: Ashgate Publishing Limited.

Camp, N. H. (2012). The Influence of Parental Involvement in Single-Father, Single-Mother, and Heterosexual, Married Two-Parent Family Systems on Adolescent Internalizing and Externalizing Behaviors (Doct. Diss.). Bouvé College of Health Sciences, Northeastern University. Boston, MA. Retrieved from https://repository.library.northeastern.edu/files/neu:966/fulltext.pdf

Downey, D. B., Ainsworth-Darnell, J. W., \& Dufur, M. (1998). Sex of Parent and Youths' Well-Being in Single-Parent Households. Journal of Marriage and the Family, 60, 878-893. https://doi.org/10.2307/353631

Dufur, M. J., Howell, N. C., Downey, D. B., Ainsworth, J. W., \& Lapray, A. J. (2010). Sex Differences in Parenting Behaviors in Single-Mother and Single-Father Households. Journal of Marriage and Family, 72(5), 1092-1106. https://doi.org/10.1111/j.1741-3737.2010.00752.x

Eggebeen, D., Snyder, A., \& Manning, W. (1996). Children in single-father families in demographic perspective. Journal of Family Issues, 17(4), 441-465. https://doi.org/10.1177/019251396017004002

Fromm, E. (1956). The Art of Loving: An Enquiry into the Nature of Love (pp. 41-43). New York: Harper \& Row. Retrieved from http://lust-for-life.org/Lust-For-Life/_Textual/ErichFromm_TheArtOfLoving_1956_148pp/ ErichFromm_TheArtOfLoving_1956_148pp.pdf .

Garasky, S., \& Meyer, D. (1996). Reconsidering the increase in father-only families. Demography, 33(3), 385-393. https://doi.org/10.2307/2061769

Gomzikova, S. (2011). Kak trudno byt'papoj.10.28.2011. Retrieved from http://svpressa.ru/society/article/46942/ http://svpressa.ru/society/article/46942/

Grabmeier, J. (1998). Single mothers, fathers equally successful at raising children. Retrieved from https://researchnews.osu.edu/archive/singpar.htm

Grozdej E. V. (2011). Ossobennosti vospitaniyadetejotsom-odinochkoj. Retrieved from http://conf.grsu.by/ alternant/2011/04/14/207/

Klyotsina, I. S. (2011). Gendernyj podkhod v psikhologicheskikh issledovaniyakh sovremennykh semejnykh otnoshenij. Vestnik LGU im. A. S. Pushkina, (4), 107-119.

Kon, I. S. (1988). Rebyonok i obshchestvo: (istoriko-etnograficheskaya perspektiva). AN SSSR, In-t etnografiyi im. N.N. Miklukho-Maklaya. - Moskva: Nauka, 269s.

McQuillan, K., \& Belle, M. (1999). Lone-father families in Canada, 1971-1996. In Annual Meeting of the Canadian Population Society, 13(8). Quebec, Canada: PSC Discussion Papers Series.

Meyer, D., \& Garasky, S. (1993). Custodial fathers: Myths, realities and child support policy. Journal of Marriage and Family, 55(1), 73-89. https://doi.org/10.2307/352960

OECD. (2011). Families are changing. In Doing Better For Families, OECD Publishing. https://doi.org/10.1787/9789264098732-3-en 
Ostavleniye detej pri razvod'e s otsom. (2016). Retrieved from http:/helprazvod.ru/razvod/yuridicheskiemomenty/kak-ostavit-detej-s-otcom.html\#ixzz4S4p1Bpo9

Otsy-odinichki v Rossii. (2010). Retrieved from https://ria.ru/spravka/20100806/262415478.html

Ovcharova R. V. (2010) Stadartizatsiya metodiki issledovaniya motovatsionno-potrebnostnojsfery otsovstva. In R. V. Ovcharova, \& Y. A. Tokareva, Izvestiya Ural'skogo gosudarstvennogo universiteta (Ser. 1). Problemy obrazovaniya, nauki i kul'tury, 3(78), 75-82.

Popov, V. A., \& Anikina, R. V. (2014). Sotsial'no-pravovoyepolozheniye otsov-odinochekvstranakh Zapadnoj Evropy, SSHAiRossiyi. Teoriya i praktikaobshchestvennogorazvitiya, 8, 73-75.

Popov, V. A. (2013). Sovremennyjepedagogicheskiyedissertatsionnyjeissledovaniyai sotsial' nyjzakaz obshchestva. Pedagogika: nauch.-teoretich.zhourn. Ross. akad.obrazovaniya, 5, 18-23.

Saralieva, Z. K., Petrova, I. E., \& Egorova, N. Y. (2015). Parenthood and Parenting in Modern Russia. Asian Social Science, 11(3), 255-261. https://doi.org/10.5539/ass.v11n3p255

Single parents worldwide: Statistics and trends. (2015). Retrieved from https://spacedoutscientist.com/2015/04/ 11/single-parents-worldwide-statistics-and-trends/

Single-parent families. (2016). Retrieved from http://www.healthofchildren.com/S/Single-Parent-Families.html

Williams, L. (2015). Experiences of Single Fathers Whose Children Used Mental Health Services (Doct. Thesis). Univ. of East London, May 2015. Retrieved from http://roar.uel.ac.uk/4535/1/Laura\%20Williams.pdf

Zhouravlev, K. (2008). The War against Fathers?! Legalized Patricide in Russia and the World over. Retrieved from http://kir-zhuravlyov.livejournal.com/4525.html

\section{Copyrights}

Copyright for this article is retained by the author(s), with first publication rights granted to the journal.

This is an open-access article distributed under the terms and conditions of the Creative Commons Attribution license (http://creativecommons.org/licenses/by/4.0/). 